\title{
PERFORMA BENIH TIRAM MUTIARA (Pinctada maxima) DARI HASIL PERSILANGAN INDUK ALAM
}

\author{
Ida Komang Wardana\#, Sudewi, Sari Budi Moria Sembiring, dan Ahmad Muzaki \\ Balai Besar Penelitian dan Pengembangan Budidaya Laut
}

(Naskah diterima: 4 Februari 2015; Revisi final: 28 Agustus 2015; Disetujui publikasi: 2 September 2015)

\begin{abstract}
ABSTRAK
Tiram mutiara merupakan salah satu komoditas andalan dalam budidaya laut. Masalah utama yang dihadapi adalah pasok benih baik kuantitas maupun kualitas. Upaya perbaikan dilakukan dengan perkawinan silang antar varietas tiram dengan tujuan untuk memperbaiki kualitas benih Tiram Mutiara (Pinctada maxima) baik secara fenotip maupun genotip. Induk yang disilangkan secara resiprokal mempunyai karakter nacre putih (P) dan kuning (K) baik populasi Bali maupun Maluku. Hasil penelitian menunjukkan bahwa persilangan dua populasi tersebut menghasilkan tiga varietas yaitu: varietas I $(\mathrm{K} \times \mathrm{P})$, varietas II $(\mathrm{K} \times \mathrm{K})$ dan varietas III $(\mathrm{P} \times \mathrm{K})$. Nilai SR pada fase pediveliger dari ketiga varietas menghasilkan sintasan berturut-turut 65\%, 59\%, dan $45 \%$. Pertumbuhan varietas III menunjukkan pertumbuhan yang cukup baik dengan kisaran panjang cangkang 3,0-4,5 cm pada umur dua bulan pemeliharaan. Analisis genetik dengan RAPD-DNA menunjukkan bahwa induk-induk yang berhasil memijah mempunyai variasi genetik 0,$3755 ; 0,3938$; dan 0,1600 . Sedangkan turunan F1 mempunyai variasi genetik lebih rendah yaitu: 0,2738; 0,2667; dan 0,0924.
\end{abstract}

KATA KUNCI: benih tiram mutiara (Pinctada maxima), perkawinan silang

ABSTRACT: Perfomance of seeds pearl oyster (Pinctada maxima) seeds as a results of cross breeding between natural. By: Ida Komang Wardana, Sudewi, Sari Budi Moria Sembiring, and Ahmad Muzaki

Pearl oyster is one of important mariculture commodity. Main constrains in the development of pearl culture is availability of seeds in terms of quality and quantity. The production and the quality of pearl oyster seed, which is still low, are caused by seed mortalities showed by the low level of survival rates. An effort to improve seeds quantity and quality, reciprocal crossing between natural stocks of Bali and Maluku have been carried out. Both populations having character coloration white nicre (P) and yellow (K). Reciprocal crossing resulting in three strain i.e. strain I (Kx $P$ ), strain II $(K \times K)$ and strain III (Px K). Survival rates at pediveliger stage higher than inbreed with value of 65\%, 59\%, and $45 \%$ respectively. Genetic analysis by RAPD-DNA of spawned broodstock shows higher genetic variation than that $F 1$. The genetic variation of broodstock were $0.3755,0.3938$, and 0.1600 respectively, while F1 of $0.2738,0.2667$, and 0.0924 respectively.

KEYWORDS: $\quad$ pearl oyster (Pinctada maxima) seeds; cross breeding

\section{PENDAHULUAN}

Tiram mutiara (Pinctada maxima) merupakan salah satu komoditas andalan budidaya laut yang sudah berkembang di beberapa lokasi di perairan Indonesia dengan produksi yang semakin meningkat (Rose et al., 1990; Hamzah, 2007). Dengan peningkatan produksi dan target capaian dari pembudidaya, maka kebutuhan akan benih dengan ukuran tertentu semakin banyak. Permasalahan yang dihadapi dalam

\# Korespondensi: Balai Besar Penelitian dan Pengembangan Budidaya Laut. Jl. Br. Gondol Kec. Gerokgak Kab. Buleleng, Kotak Pos 140, Singaraja, Bali 81101, Indonesia. Tel.: + (0362) 92278 E-mail: info.gondol@gmail.com budidaya tiram mutiara adalah masih rendahnya produksi benih, yang diduga karena pada tahap pemeliharaan larva banyak mengalami kematian pada umur tertentu dengan tingkat sintasan (SR) cukup rendah (kurang dari 10\%) (Supii et al., 2009; Lind et al., 2009). Pada penelitian tahun 2011, diperoleh benih dari pemijahan induk dengan karakter cangkang dalam (nacre) putih dengan SR berkisar antara 0,4\%-9\% (Supii et al., 2011). Rendahnya tingkat sintasan benih yang dihasilkan, sangat tergantung dari induk yang digunakan dan manajemen perbenihan terutama pada tahap awal perkembangan larva. Tahap larva jenis kekerangan merupakan masa yang sangat kritis karena pada stadia tersebut larva mengalami beberapa kali metamorfosis yang membutuhkan nutrisi, lingkungan 
dan penanganan yang baik, sehingga larva akan mengalami kematian apabila ada salah satu faktor tidak terpenuhi. Berdasarkan hal tersebut, pemantauan terhadap tahap perkembangan awal larva perlu dilakukan untuk mengurangi tingkat kematian pada umurumur tertentu sehingga sintasan larva dapat ditingkatkan.

Di alam diketahui bahwa tiram mutiara ada yang memiliki warna nacre kuning dan putih, akan tetapi populasi tiram dengan nacre putih sangat jarang dibandingkan nacre kuning (komunikasi pribadi, Bapak Alim, Bima Budidaya Mutiara). Secara ilmiah adanya perbedaan warna nacre tersebut belum dapat dijelaskan secara rinci, kemungkinan karena faktor lingkungan atau faktor kedalaman. Tiram dengan nacre kuning, unggul dalam hal produksi benih, sementara nacre putih dicari mantelnya untuk digunakan sebagai saibo yang berpengaruh terhadap kualitas dan warna mutiara yang dihasilkan. Upaya yang ditempuh untuk memenuhi permintaan pasar akan benih adalah dengan melakukan perbaikan perbenihan, terutama dalam hal memproduksi benih yang tahan terhadap perubahan lingkungan. Perbedaan fenotipik dan habitat induk alam yang digunakan dalam pembenihan dimungkinkan memberikan kemampuan fitness individu yang berbeda sehingga diharapkan dapat menghasilkan kualitas benih lebih baik. Hibridisasi merupakan suatu teknik modifikasi perkawinan baik antar individu atau kelompok yang berbeda secara genetik, termasuk di dalamnya perkawinan dalam suatu spesies ataupun antara spesies yang berbeda. Teknik ini biasanya digunakan oleh pembudidaya untuk menghasilkan individu/populasi dengan ciri atau sifat yang diinginkan, umumnya untuk menghasilkan keturunan yang memiliki performa yang lebih baik dibandingkan dengan para tetuanya (Falcouner \& Mackey, 1996; Bartley et al., 2001). Beberapa kajian tentang hibridisasi pada komoditas tiram penghasil mutiara antara lain pada jenis Pinctada fucata, Pinctada martensii (Wang et al., 2005; Yu et al., 2009) dan Crassostrea sp. (Gaffney et al., 1993). Perbenihan dengan menggunakan teknik perkawinan silang dari induk yang berbeda habitat perlu diinisiasi agar managemen perbenihan lebih terarah dan dapat dilakukan perbaikan. Tujuan penelitian ini adalah mengeta- hui kualitas benih tiram mutiara secara fenotip dan genotip yang dihasilkan melalui perkawinan silang induk alam yang memiliki karakter nacre putih dan kuning. Melalui penelitian ini, diharapkan memperoleh varietas tiram mutiara berupa benih yang memiliki karakter cepat tumbuh, tahan terhadap perubahan lingkungan dan dapat dijadikan sebagai calon tiram untuk operasi yang mampu menghasilkan mutiara dengan kualitas baik.

\section{BAHAN DAN METODE}

\section{Pembenihan Tiram Mutiara}

Langkah awal yang dilakukan adalah koleksi induk alam (F0) yang memiliki karakter nacre putih dan kuning dari perairan Bali Selatan dan perairan Kepulauan Maluku (Dobo). Pemilihan induk alam dari dua perairan tersebut, berdasarkan dari hasil pengamatan secara genetik, dua populasi yang digunakan memiliki perbedaan dari segi nilai allel frekuensi yang dipotong menggunakan enzim restriksi Dde I (Bali empat jenis allel, sedangkan populasi Maluku dengan lokus yang sama memiliki dua jenis allel (Supii et al., 2011). Sehingga dengan menggunakan induk dari kedua perairan tersebut, terjadi aliran gen yang baik kepada turunan yang akan dihasilkan. Kemudian aklimatisasi induk pada perairan Gondol dan perbenihan dilakukan dengan metode perkawinan silang antara induk yang berasal dari Bali Selatan dan perairan Maluku. Teknik perkawinan silang yang diterapkan antara lain pemijahan tiram nacre putih Maluku ( $₫$ ) dengan Bali ( $q$ ), pemijahan nacre kuning Maluku ( $₫$ ) dengan Bali ( $q$ ), dan pemijahan nacre putih Bali dengan nacre kuning Maluku atau sebaliknya (Bali + , Maluku ô) (Tabel 1).

Pemijahan dilakukan dengan menggunakan 50 pasang induk dari masing-masing perairan. Dari pasangan induk tersebut, induk yang menunjukkan matang gonad sempurna yang dipilih dan dipijahkan. Keberhasilan memperoleh benih dari masing-masing pemijahan tersebut diharapkan sebesar 50\%. Benih dipelihara di laut setelah proses pemeliharaan di hatcheri ( \pm 45-50 hari) dan dilakukan pengamatan fenotipik, sampling pertumbuhan serta grading benih yang menunjukkan variasi pertumbuhan. Benih yang

Tabel 1. Metode perkawinan silang tiram mutiara dari dua populasi yang berbeda

Table 1. The method of pearl oyster cross breeding derived from two populations

\begin{tabular}{|c|c|c|c|}
\hline \multirow{4}{*}{$\begin{array}{l}\text { Maluku } \\
\text { (F0) }\end{array}$} & \multirow{2}{*}{$\begin{array}{l}\text { Perkawinan silang } \\
\text { Cross breeding }\end{array}$} & \multicolumn{2}{|c|}{ Bali (F0) } \\
\hline & & q Putih (White) & 우 Kuning (Yellow) \\
\hline & o Putih (White) & F1 Varietas (Variety) IV & F1 Varietas (Variety) I \\
\hline & đ Kuning (Yellow) & F1 Varietas (Variety) III & F1 Varietas (Variety) II \\
\hline
\end{tabular}


sudah terseleksi dipelihara lebih lanjut untuk pemantauan kualitas hingga menjadi yuwana $( \pm 8$ minggu).

\section{Keragaan Genetik}

Jaringan dari induk (F0) dan benih (F1) yang dihasilkan, diambil sebagai bahan analisis untuk mengetahui keragaan genetik, sampel F0 sesuai dengan jumlah induk yang berhasil memijah dan F1 dari masing-masing varietas sebanyak 15 ekor. Jaringan mantel yang sudah diambil diekstraksi dengan menggunakan metode Ovenden (2000) yang dimodifikasi. Hasil ekstraksi kemudian dipurifikasi menggunakan High Pure Purification kit (Roche) dan selanjutnya tingkat kemurnian DNA diukur menggunakan Gene Quant Machine.

Langkah berikutnya adalah optimasi primer dengan melakukan amplifikasi PCR yang bertujuan untuk mendapatkan fragment DNA tunggal. Primer yang digunakan untuk mengamplifikasi sampel DNA tiram mutiara adalah primer Cytochrome Oxidase I (COI) forward : 5"- ATA ATG ATA GGA GGR TTT GG- 3" dan reverse 5" - GCT CGT GTR CTA CRT CCA T - 3" (Williams \& Banzie, 1997). Hasil amplifikasi difragmentasikan menggunakan agarose gel dan didokumentasikan pada geldock polaroid dengan menggunakan UV transilluminator. Genom DNA sampel yang sudah teramplifikasi sempurna, untuk mengetahui variasi genetik dari F0 dan F1 hasil perkawinan si- lang dilakukan pemotongan dengan beberapa RE (Restriction enzyme) antara lain : Fok I, Mbo I, Mnl I, Msp I dan Nla IV (Biolabs). Dari hasil pemotongan tersebut, dilakukan skoring dan data yang diperoleh dianalisa dengan menggunakan UPGMA (Unweighted Pair Group Methode by Average) dalam software TFPGA (Bermingham, 1990). Parameter yang diamati meliputi: karakter fenotip benih yang dihasilkan, sintasan benih (SR), keragaan genetik induk dan benih hasil perkawinan silang.

\section{HASIL DAN BAHASAN}

Perkawinan silang tiram mutiara antar dua populasi dapat dilakukan dengan hasil yang cukup baik, akan tetapi perlu diperhatikan kondisi induk yang digunakan, terutama observasi terhadap tingkat kematangan gonadnya. Karena dengan kematangan gonad yang sempurna masing-masing individu (jantan dan betina), kemungkinan terjadinya pemijahan cukup tinggi. Berdasarkan hasil yang diperoleh, Tabel 2 menunjukkan bahwa dari empat target pemijahan silang (perkawinan sebelah) yang diasumsikan, hanya tiga perkawinan yang memberikan data yang lengkap. Pemijahan tersebut antara lain perkawinan tiram nacre kuning (Bali) dengan putih (Maluku), perkawinan nacre kuning (Bali) dengan kuning (Maluku) dan perkawinan nacre putih (Bali) dengan kuning (Maluku). Sedangkan perkawinan tiram dengan nacre putih dari kedua populasi tidak bisa terlaksana sampai akhir

Tabel 2. Data pemijahan tiram mutiara dari hasil perkawinan silang induk alam

Table 2. Data of pearl oyster spawning resulted from cross breeding of wild brood stocks

\begin{tabular}{|c|c|c|c|c|}
\hline \multirow{2}{*}{$\begin{array}{l}\text { Parameter } \\
\text { Parameters }\end{array}$} & \multicolumn{4}{|c|}{ Pemijahan silang (Cross spawning ) } \\
\hline & $\begin{array}{c}\text { K (Bali) X } \\
\text { P (Maluku) }\end{array}$ & K x K & $\begin{array}{c}\text { P (Bali) x } \\
\text { K (Maluku) }\end{array}$ & $\mathbf{P} \times \mathbf{P}$ \\
\hline Bulan memijah (Spawning periode) & Maret 2012 & Juni 2012 & Juni 2012 & - \\
\hline $\begin{array}{l}\text { Jumlah induk yang memijah } \\
\text { Number of spawned broodstock }\end{array}$ & 3 ㅇ 55 o & 5 ㅇ (Bali) x $7 ð$ (Maluku) & $2+\times 3 \stackrel{0}{\circ}$ & - \\
\hline Jumlah telur (butir) (Total eggs (pcs)) & $2,200,000$ & $2,000,000$ & $2,700,000$ & - \\
\hline Daya tetas telur (Hatching rate) $(\%)$ & 81.8 & 70 & 3.7 & - \\
\hline Jumlah larva D1 (veliger) (Number of veliger) & $1,800,000$ & $1,400,000$ & 100,000 & - \\
\hline $\begin{array}{l}\text { Sintasan stadia pediveliger } \\
\text { SR of pediveliger stage (\%) }\end{array}$ & 65 & 59 & 45 & - \\
\hline Jumlah spat (ekor) (Total of spat (pcs)) & 7,325 & 11,055 & 1,871 & - \\
\hline Sintasan spat (D45) (SR of spat stage (\%)) & 0.4 & 0.8 & 1.8 & - \\
\hline $\begin{array}{l}\text { Sintasan benih ukuran lebih dari } 2 \mathrm{~cm} \\
\text { SR of fry with } 2 \mathrm{~cm} \text { up size (\%) }\end{array}$ & 8.5 & 6.4 & 61 & - \\
\hline
\end{tabular}

Keterangan (Note):

$\mathrm{K}=$ Kuning (Yellow), $\mathrm{P}=$ Putih (White)

Pemijahan nacre putih x putih selama masa penelitian tidak dapat berlangsung (White nacre $\mathrm{x}$ white spawning during observation can not be done) 
penelitian karena setiap dilakukan observasi tingkat kematangan gonad, induk-induk tersebut sebagian besar berupa individu jantan, sementara individu betina sangat jarang diperoleh dan menunjukkan tingkat gonad betina yang belum sempurna, sehingga setiap proses pemijahan, pasangan tersebut memberikan respon yang kurang baik. Turunan dari masingmasing perkawinan silang tersebut antara lain benih varietas I, varietas II, dan varietas III. Perkawinan pasangan I berlangsung pada bulan Maret, dari 15 induk yang matang gonad, hanya lima induk jantan dan tiga induk betina yang berhasil memijah. Pemijahan tersebut menghasilkan telur yang dibuahi sebanyak 2.200 .000 butir dengan hatching rate (HR) $81 \%$. Sementara perkawinan pasangan induk II dan III berlangsung pada bulan yang sama yaitu Juni 2012, masing-masing menunjukkan jumlah induk yang berhasil memijah sebanyak lima betina, tujuh jantan (pasangan II) dan pasangan III yang terdiri dari dua betina dan tiga jantan. Jumlah dan HR dapat dilihat pada Tabel 2, untuk pasangan induk III HR-nya cukup rendah dibanding dengan $H R$ yang lain, hal tersebut kemungkinan karena kualitas telur dan sperma yang dihasilkan oleh pasangan induk tersebut kurang baik, sehingga pada proses pembelahan sel banyak telur tidak berhasil membelah dengan sempurna dan larva yang diperoleh pada tahap veliger (fase D) hanya sebanyak 100.000 ekor $(3,7 \%)$. Apabila ditinjau dari segi proses pemijahan, pasangan tersebut mengeluarkan sperma dan sel telur relatif banyak ( $\pm 5000 \mathrm{sel} /$ $\mathrm{mL}$ ), akan tetapi setelah diinkubasi pada bak penetasan hanya $2 \%$ yang berhasil membelah menjadi veliger.

Pada tahap pediveliger, sintasan (SR) dari masingmasing varietas cukup baik yaitu berkisar antara 45\%$65 \%$. Berdasarkan dari pengamatan perkembangan stadia larva dari tahap veliger sampai tahap spat, benih dari hasil perkawinan silang masing-masing menunjukkan perbedaan waktu perubahan stadia, warna larva dan warna cangkang mulai memasuki stadia spat (Tabel 3). Benih varietas I, pada awal perkembangannya cukup baik, karena didukung oleh faktor lingkungan yang stabil, ditandai dengan perubahan antar stadia relatif cepat dibandingkan dengan perkembangan normal larva tiram berdasarkan Ellis \& Haws, (2002). Akan tetapi hal tersebut perlu dikaji kembali, karena pemijahan silang dari masing-masing varietas hanya berlangsung satu kali dan semua faktor lingkungan diupayakan terkontrol dengan baik pada tahap pemeliharaan di hatcheri. Sementara pada saat pemeliharaan larva varietas II dan III berlangsung, suhu perairan cukup berfluktuasi terutama pada pagi hari, karena pemeliharan larva tersebut berlangsung pada pertengahan bulan Juni sampai Agustus dengan kisaran suhu berkisar antara $26^{\circ} \mathrm{C}-28^{\circ} \mathrm{C}$.
Berdasarkan hasil pemantauan Hanafi et al. (2008b), bahwa pada bulan Juni sampai Agustus setiap tahunnya merupakan kondisi yang kurang baik bagi komoditas ikan budidaya, termasuk benih tiram mutiara. Larva tiram varietas II dan III yang dipelihara pada hatcheri pada bulan-bulan tersebut, untuk menghindari tingkat mortalitas yang tinggi karena pengaruh turunnya suhu air media pemeliharaan, dilakukan pergantian air lebih sering dibandingkan dengan pemeliharaan normal. Sedangkan benih varietas I yang dibesarkan pada long line di laut dengan ukuran 1-1,5 $\mathrm{cm}$ pada bulan tersebut banyak mengalami kematian $( \pm 60 \%)$. Selain dari pengaruh turunnya/fluktuasi suhu perairan, adanya kematian pada komoditas budidaya, juga disebabkan oleh perubahan pola arus yang berdampak pada naiknya sedimen berupa lumpur yang menyebabkan air menjadi keruh dan memberikan pengaruh negatif terhadap sintasan komoditas budidaya. Fenomena tersebut nampak pada sarana pembesaran benih varietas I yang berupa pocket benih dan kerangka kubus banyak tertutup lumpur, sehingga sirkulasi pakan terhambat yang berakibat pada kematian benih. Berdasarkan hal tersebut, untuk mengantisipasi kejadian yang sama pada tahun berikutnya, diperlukan pencegahan antara lain dengan cara pergantian waring kubus lebih sering, penempatan benih pada kedalaman kurang dari $3 \mathrm{~m}$, pemindahan sementara benih pada bak terkontrol (indoor) dan tidak melakukan penebaran benih pada bulan-bulan tersebut.

Ditinjau dari morfologi warna benih dan waktu pergantian stadia dari semua varietas yang dihasilkan, nampak ada perbedaan pada tahap veliger, spat muda dan yuwana umur satu bulan (Tabel 3). Varietas I pada tahap veliger (tahap D) identik dengan warna merah sama dengan larva tiram pada umumnya, sementara varietas II berwarna putih dan varietas III menunjukkan warna putih pucat. Spat yang menempel pada kolektor untuk varietas I dominan warna putih, varietas II putih abu-abu dan warna coklat muda mendominasi warna spat varietas III. Apabila dibandingkan dengan warna yuwana (satu bulan di laut) dengan ukuran cangkang 0,8-1,5 cm semua varietas, sebagian besar benih menunjukkan pola warna yang sama dengan adanya warna hijau, hitam, coklat tua dan kuning (Gambar 1). Terjadinya perbedaan warna pada tahap awal larva dan spat muda, kemungkinan disebabkan oleh perbedaan habitat dari induk alam yang digunakan dan karena pengaruh perkawinan silang. Akan tetapi setelah memasuki stadia yuwana semua varietas menunjukkan pola warna yang tidak berbeda karena proses pembesaran di laut pada perairan yang sama (Gambar 1). Hal tersebut juga didukung oleh pernyataan Doroudi \& Southgale (2002) dan Hermawan (2007), bahwa warna cangkang yang 
Tabel 3. Perkembangan stadia larva dari masing-masing varietas hasil perkawinan silang antar populasi alam Table 3. Development of larval stages generated from cross breeding between wild stock populations

\begin{tabular}{|c|c|c|c|c|c|}
\hline \multirow{2}{*}{$\begin{array}{l}\text { Perkembangan stadia } \\
\text { Development of stages }\end{array}$} & \multicolumn{4}{|c|}{$\begin{array}{l}\text { Perkawinan silang antar populasi } \\
\text { Cross breeding between populations }\end{array}$} & \multirow{2}{*}{$\begin{array}{c}\text { Normal } \\
\text { (Ellis \& Haws, 2002) }\end{array}$} \\
\hline & $\mathrm{K}($ o $) \times \mathbf{P}(\overbrace{}^{\star})$ & K( $(+) \mathbf{x} K\left(ठ^{\star}\right)$ & $\mathbf{P}(+\circ) \times \mathbf{K}\left(0^{*}\right)$ & $\mathbf{P}(q) \times \mathbf{P}(\circlearrowleft)$ & \\
\hline Veliger & D1 - D6 & D1 - D6 & D1 - D7 & - & D1 - D12 \\
\hline Umbo & D7 - D16 & D7 - D14 & D7 - D16 & - & D13 - D14 \\
\hline Pediveliger & D17 & D15 & D17 & - & D18 - D20 \\
\hline Plantigrade & D19 & D20 & D19 & - & D20 - D22 \\
\hline Postlarva & D24 & D23 & D23 & - & D25 \\
\hline Spat & D30 & D28 & D28 & - & D30 - D35 \\
\hline $\begin{array}{l}\text { Warna larva } \\
\text { Color of larvae }\end{array}$ & $\begin{array}{l}\text { Merah } \\
\text { Red }\end{array}$ & $\begin{array}{l}\text { Putih } \\
\text { White }\end{array}$ & $\begin{array}{l}\text { Putih pucat } \\
\text { Pale white }\end{array}$ & - & $\begin{array}{l}\text { Merah } \\
\text { Red }\end{array}$ \\
\hline $\begin{array}{l}\text { Warna spat awal } \\
\text { Initial color of spat }\end{array}$ & $\begin{array}{l}\text { Putih pucat } \\
\text { Pale white }\end{array}$ & $\begin{array}{l}\text { Putih abu-abu } \\
\text { Greyish white }\end{array}$ & $\begin{array}{l}\text { Coklat muda } \\
\text { Light brown }\end{array}$ & - & $\begin{array}{l}\text { Putih, tergantung dari } \\
\text { pakan yang diberikan } \\
\text { White, depending on } \\
\text { feed given }\end{array}$ \\
\hline $\begin{array}{l}\text { Kisaran suhu } \\
\text { Range of temperature }\left({ }^{\circ} \mathrm{C}\right)\end{array}$ & $28-30$ & $26-28$ & $26.5-28.0$ & - & \\
\hline
\end{tabular}




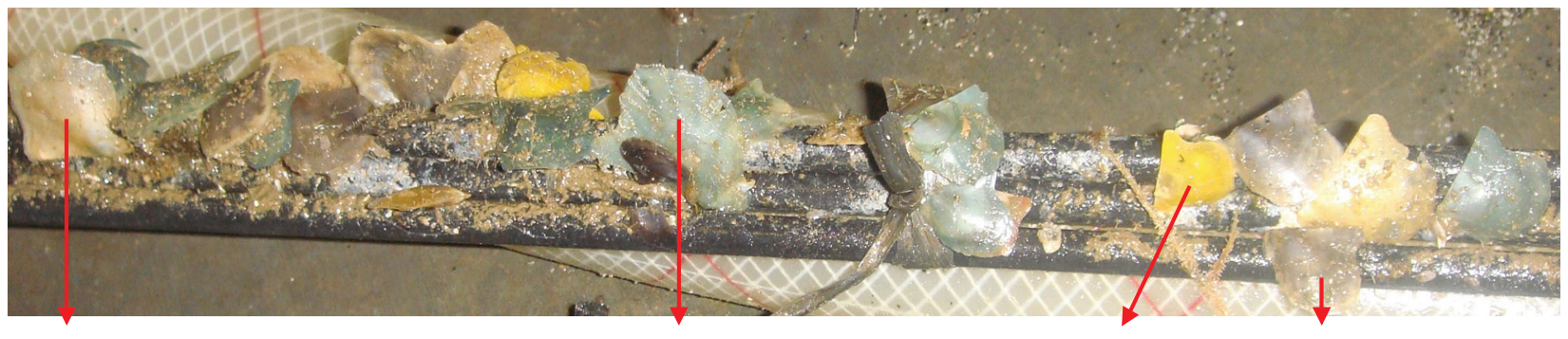

Coklat (Brown)

Hijau (Green)

Kuning (Yellow) Abu-abu (Grey)

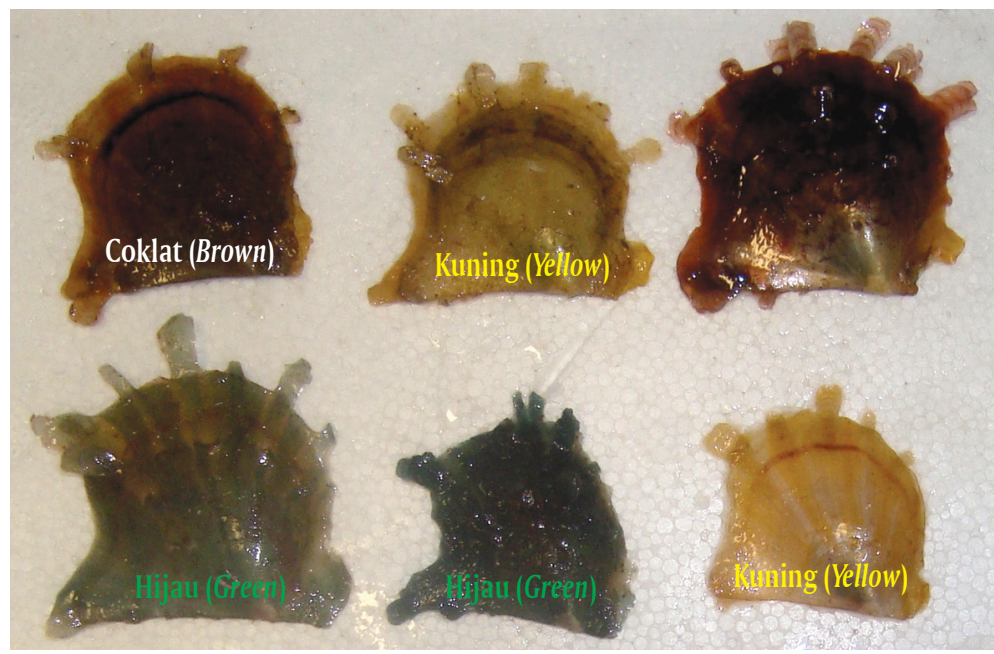

Gambar 1. Pola warna yang terbentuk pada spat dan yuwana muda dari semua varietas

Figure 1. Spat and juvenile color pattern of all varieties

terbentuk pada populasi benih tiram pada tahap awal perkembangan akan memberikan pola warna yang bervariasi tergantung jenis pakan yang diberikan dan kekayaan perairan tempat pembesaran benih dilakukan. Pada penelitian ini, jenis pakan alami yang diberikan dari stadia veliger sampai spat (D1-D45) berupa campuran dari mikroalga jenis Isochrysis sp., Pavlova sp., Chaetocheros sp., dan Nannochloropsis sp. Untuk perkembangan tahap awal (D1-D17) cukup baik diberikan pakan hanya berupa Isochrysis sp. dan Pavlova sp. dengan kepadatan $8.000 \mathrm{sel} / \mathrm{mL}$ atau lebih, karena kandungan nutrisi dari jenis pakan alami tersebut sudah memenuhi kebutuhan pakan untuk perkembangan larva tersebut dan benih lebih tahan setelah ditebar di laut. Pada perairan bebas, benih secara leluasa menyaring pakan yang tersedia pada perairan tempat benih dibesarkan. Berdasarkan data dari penelitian Hanafi et al. (2007, 2008a), menyatakan bahwa perairan Pegametan dan Gondol merupakan perairan yang kaya dengan telah teridentifikasi 59 jenis mikroalga dan parameter lingkungan yang masih layak untuk kegiatan budidaya, akan tetapi tetap perlu dilakukan monitoring sebagai upaya mencegah terjadinya degradasi lingkungan budidaya yang bisa merugikan banyak pihak pada masa yang akan datang. Sementara berdasarkan waktu pergantian stadia perkembangan larva, secara keseluruhan tidak berbeda secara signifikan, hanya varietas II dan III pada tahap spat lebih cepat dua hari dibandingkan dengan varietas I.

Sintasan benih hasil perkawinan silang menunjukkan nilai yang lebih baik dibandingkan dengan benih dari hasil perkawinan satu populasi. Hal tersebut dapat dilihat pada Tabel 4, yang menunjukkan perbedaan SR pada stadia pediveliger, spat dan yuwana antara hasil persilangan dengan pemijahan satu populasi. Pada stadia pediveliger dari semua varietas menunjukkan nilai lebih dari 40\%, setelah memasuki stadia spat, jumlah benih yang berhasil menempel pada substrat relatif sedikit. Rendahnya tingkat sintasan benih dari stadia pediveliger menjadi spat, disebabkan oleh proses metamorfosis dari fase planktonik menjadi fase bentik (menempel) yang membutuhkan banyak energi, kemampuan adaptasi dari masingmasing individu tidak seragam dan pengaruh faktor lingkungan yang kurang stabil. Hal tersebut juga dipertegas oleh pernyataan Dhoe et al. (2001), Winanto (2004), Direktorat Jenderal Perikanan Budidaya (2004), yang menyebutkan bahwa faktor yang berpengaruh terhadap sintasan benih tiram mutiara antara lain: kondisi biofisik perairan (suhu, pH, DO, salinitas), adanya bahan pencemar, kedalaman, substrat dasar, kecerahan, adanya asupan air tawar, pola arus dan 
Tabel 4. Sintasan pada tahap pediveliger dan spat antar perkawinan silang dengan perkawinan satu populasi

Table 4. Survival rates (SR) at the pediveliger and spat stages of the between and within population breeding

\begin{tabular}{lccc}
\hline \multirow{2}{*}{$\begin{array}{c}\text { Parameter } \\
\text { Parameters }\end{array}$} & \multicolumn{3}{c}{ Sintasan (Survival rate) (\%) } \\
\cline { 2 - 4 } & Pediveliger & Spat (D45) & Benih (Seed) $\mathbf{2 ~ c m ~ u p ~}$ \\
\hline Varietas (Variety) I (K X P) & 65 & 0.4 & 8.5 \\
Varietas (Variety) II (K X K) & 59 & 0.8 & 6.4 \\
Varietas (Variety) III (P X K) & 45 & 1.8 & 61 \\
Varietas (Variety) IV (P X P) & - & - & - \\
Perkawinan murni (True breed) (Bali) & 22 & 0.1 & 1.8 \\
Perkawinan murni (True breed) (Maluku) & 16 & 0.23 & 3.5 \\
\hline
\end{tabular}

tingkat kesuburan perairan. Sintasan benih pada tahap spat $(2 \mathrm{~cm})$, setelah 40 hari pemeliharaan di laut, jumlah spat yang diperoleh dari masing-masing varietas untuk varietas I dan II dapat dikatakan cukup baik dengan nilai $8,5 \%$ dan $6,4 \%$, sedangkan benih varietas III memberikan nilai yang paling tinggi yaitu $61 \%$. Tingginya nilai SR dari varietas III mungkin disebabkan oleh penundaan pemotongan bisus pada benih ukuran 1-1,5 cm dan saat dilakukan sampling, kolektor hanya dibersihkan dari kotoran biofouling dan benih yang menempel agak padat pada satu sisi yang sama dilakukan penjarangan. Di samping itu, benih dengan ukuran cangkang kurang dari $4 \mathrm{~cm}$, ditempatkan pada kedalaman kurang dari $3 \mathrm{~m}$, yang bertujuan untuk mengurangi stres benih dari pemeliharaan di hatcheri ke perairan bebas dan untuk mempermudah benih untuk menyaring pakan alami yang terkonsentrasi pada bagian permukaan perairan.

Berdasarkan nilai beberapa parameter yang diamati pada benih hasil perkawinan silang, secara deskriptif menunjukkan performa yang lebih baik dibandingkan dengan benih hasil perkawinan satu populasi (truebreed). Hal tersebut dapat terlihat pada nilai SR dan pertumbuhan benih dari semua varietas cukup baik. Ditinjau dari jumlah benih yang diperoleh pada umur tiga bulan yang ditebar di laut, varietas III yang menunjukkan jumlah populasi yang paling tinggi, kemudian varietas II dan varietas I (Gambar 2). Berdasarkan dari variasi ukuran tubuh benih ketiga varietas menunjukkan perbedaan yang cukup signifikan (Tabel 5 dan 6). Benih varietas III yang berukuran besar (panjang cangkang $>2,5 \mathrm{~cm}$ ) $75 \%$ mendominasi, $20 \%$ berukuran $2 \mathrm{~cm}$ dan $5 \%$ memiliki ukuran $<1,5$ $\mathrm{cm}$. Sedangkan pada varietas I dan II didominasi oleh benih dengan ukuran sedang dan kecil. Seleksi yang dilakukan pada penelitian ini, ditekankan pada pemilihan benih dari semua varietas yang menunjukkan pertumbuhan cepat dan performa fenotipik yang sempurna (Gambar 3). Berdasarkan dari kriteria tersebut, benih yang terseleksi berdasarkan dari hasil sampling terakhir bulan Desember 2012 antara lain; varietas I sebanyak 225 ekor, varietas II 375 ekor dan varietas III sebanyak 500 ekor. Dengan demikian da-

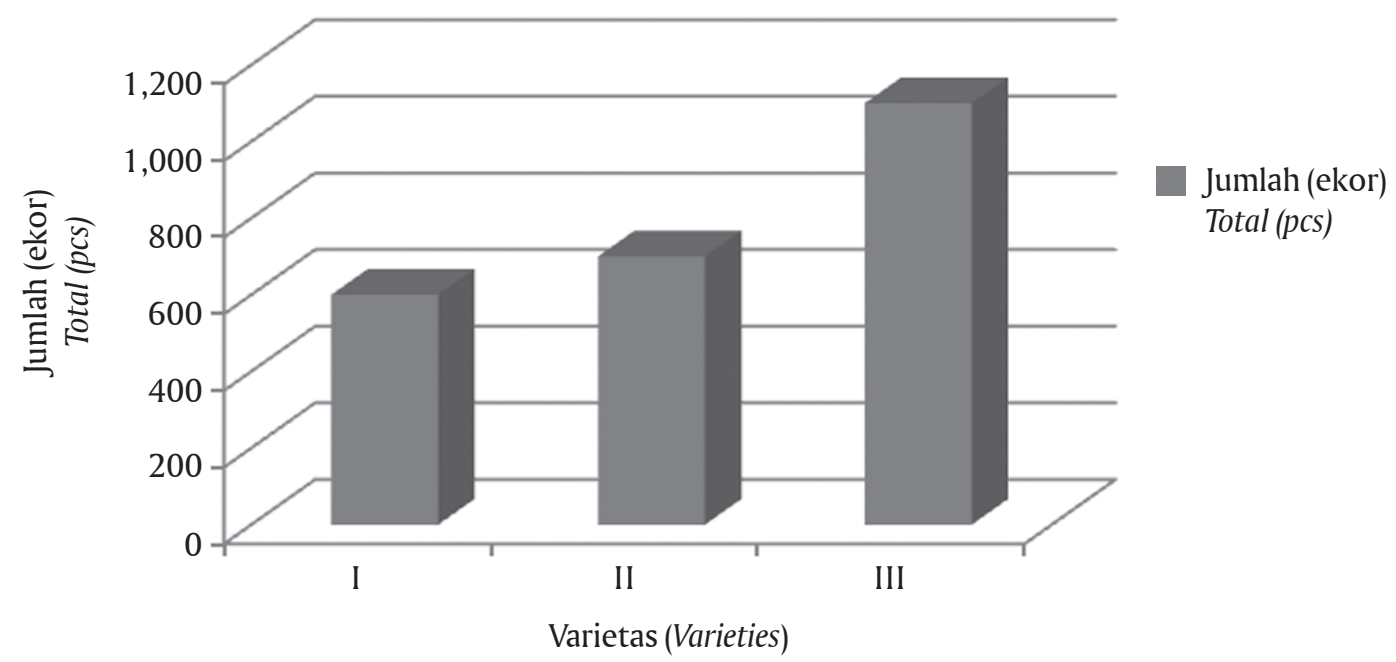

Gambar 2. Jumlah benih tiram mutiara dari hasil perkawinan silang pada akhir pengamatan

Figure 2. Number of pearl oyster seeds resulted from cross breeding at the end of observation 
Tabel 5. Pertumbuhan benih tiram mutira dari hasil pemijahan silang Table 5. The growth of pearl oyster seeds resulted from cross breeding

\begin{tabular}{rccc}
\hline \multirow{2}{*}{$\begin{array}{c}\text { Hasil pemijahan } \\
\text { Result of spawning }\end{array}$} & \multicolumn{3}{c}{ Kisaran variasi ukuran panjang nacre } \\
& \multicolumn{3}{c}{ Variation range of nacre length size $\mathbf{( c m )}$} \\
\cline { 2 - 4 } & $\begin{array}{c}\text { Awal tebar } \\
\text { Initial seeds }\end{array}$ & $\begin{array}{c}\text { Bulan I } \\
\text { Month I }\end{array}$ & $\begin{array}{c}\text { Bulan II } \\
\text { Month II }\end{array}$ \\
\hline Varietas (Variety) I & $0.2-0.3$ & $1.5-2.5$ & $0.8-3.0$ \\
Varietas (Variety) II & $0.4-0.8$ & $1.4-2.6$ & $2.5-4.3$ \\
Varietas (Variety) III & $0.4-0.9$ & $1.3-2.5$ & $3.0-4-5$ \\
Varietas (Variety) IV & - & - & - \\
\hline
\end{tabular}

Tabel 6. Variasi ukuran benih tiram mutiara dari masing-masing varietas Table 6. Variation in size of the pearl oyster seed of all varieties

\begin{tabular}{cccc}
\hline \multirow{2}{*}{$\begin{array}{l}\text { Varietas } \\
\text { Varieties }\end{array}$} & \multicolumn{3}{c}{$\begin{array}{c}\text { Variasi ukuran dalam satu populasi } \\
\text { Size variation in one population }\end{array}$} \\
\cline { 2 - 4 } & Besar (Big) (\%) & Sedang (Middle) (\%) & Kecil (Small) (\%) \\
\hline I (K X P) & 38 & 26 & 36 \\
II (K X K) & 54 & 35 & 15 \\
III (P X K) & 75 & 20 & 5 \\
IV (P X P) & - & - & - \\
\hline
\end{tabular}
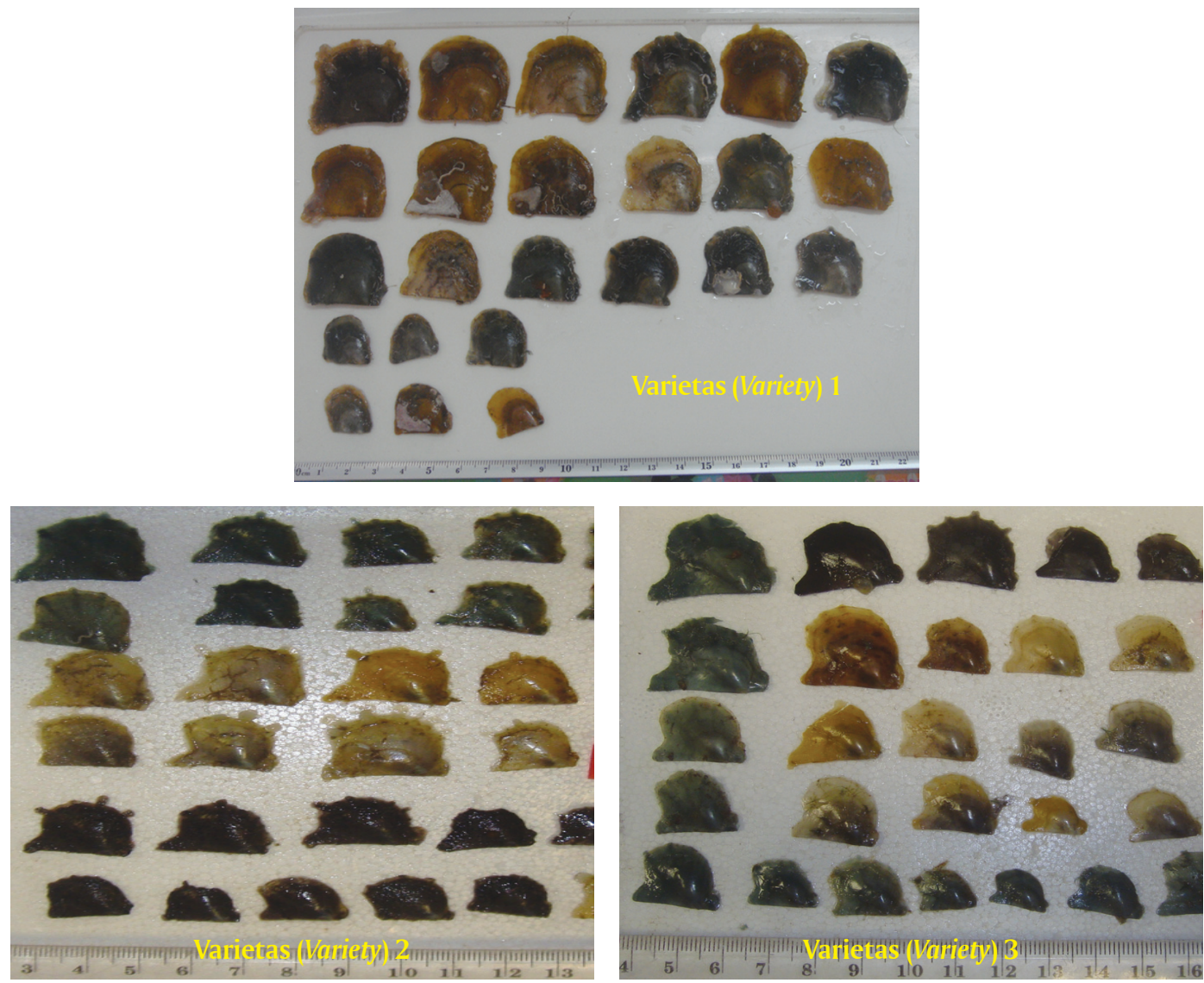

Gambar 3. Performansi benih hasil perkawinan silang dari varietas I, II, dan III

Figure 3. Performance of pearl oyster seed generated from cross breeding of variety I, II, and III 
pat dikatakan bahwa perkawinan silang tiram mutiara dengan perbedaan warna nacre dari dua populasi (Bali dan Maluku) memberikan pengaruh positif terhadap sintasan benih, performansi benih secara morfologi dan genotip. Hal tersebut juga mendukung pernyataan Gjedrem (1993) dan Tave (1995) dalam Ath-thar et al. (2011), bahwa dengan melakukan hibridisasi antar dua individu yang berbeda, maka secara tidak langsung akan mendapatkan keturunan yang lebih baik karena sifat heterosis yang ada pada banyak lokus termanfaatkan dengan baik. Kemudian Yu et al. (2009), juga menerangkan bahwa perkawinan silang tiram jenis Pinctada fucata dari dua populasi yang berbeda secara resiprok menghasilkan turunan dengan proporsi lokus polimorfik relatif tinggi (99,6\%) dan pertumbuhan benih berdasarkan panjang dan lebar cangkang lebih baik.

\section{Keragaman Genetik}

Pemantauan terhadap keragaan genetik dari induk dan benih yang dihasilkan pada penelitian ini, untuk memperoleh data dukung khususnya nilai variasi genetik hasil perkawinan silang induk alam dari dua populasi yang berbeda. Berdasarkan hasil amplifikasi induk yang berhasil memijah dan keturunan (F1) yang dihasilkan menunjukkan pola fragment yang sama yaitu teramplifikasi pada berat molekul 700 bp (Gambar 4). Hal tersebut mengindikasikan bahwa antara induk dan benih merupakan spesies yang sama dalam satu populasi tiram jenis Pinctada maxima. Varietas I induk yang berhasil memijah sebanyak tiga betina dan empat jantan, berdasarkan hasil pemotongan dengan enzim restriksi dan analisa TFPGA pasangan induk tersebut memiliki nilai variasi 0,3755 , sementara pasangan induk II yang terdiri dari empat induk jantan dan empat induk betina memberikan nilai 0,3938 dan nilai variasi 0,1600 merupakan nilai dari pasangan induk III (dua betina dan tiga jantan). Nilai variasi tersebut, jika dibandingkan dengan true breed dari masing-masing populasi (Bali dan Maluku) dapat dikatakan mengalami peningkatan (Tabel 5). Sementara pada turunan (F1) yang dihasilkan semua varietas menunjukkan nilai heterozygositas lebih rendah dibandingkan induknya. Akan tetapi jika dibandingkan dengan benih dari hasil perkawinan satu populasi (true breed), nilai variasi yang terekspresi tetap lebih baik. Adanya peningkatan nilai heterozygositas dari sampel induk yang digunakan dalam penelitian ini, dimungkinkan karena induk-induk tersebut berasal dari habitat yang berbeda dengan pola distribusi secara genetik tidak sama. Dengan demikian perkawinan dari spesies sama yang habitatnya berbeda, akan memberikan pengaruh positif terhadap peningkatan mutu genetik dari hybrid vigure yang secara langsung dapat dilihat pada performa turunan yang dihasilkan.

Berdasarkan hasil analisa RFLP dengan menggunakan lima jenis enzim restriksi (Fok I, Mbo I, Mnl I, Msp I dan Nla IV) dari masing-masing populasi menunjukkan pola pemotongan yang bervariasi baik pada pasangan induk maupun pada turunannya (Gambar 5, Tabel 7). Fok I, Msp I dan Nla IV memberikan tiga jenis sisi pemotongan yaitu: satu sisi, dua dan tiga sisi pada berat molekul 160 bp sampai 550 bp. Sementara enzim Mbo I dan Mnl I menunjukkan tiga dan dua sisi pemotongan, akan tetapi tidak bervariasi antar sampel. Dengan demikian untuk mengetahui variasi genetik tiram mutiara jenis Pinctada maxima dapat menggunakan enzim restriksi Fok I, Msp I dan Nla IV sebagai marker. Ditinjau dari hasil analisa TFPGA semua populasi menunjukkan variasi genetik yang berbeda antar varietas dan pada anakannya (F1) mengalami penurunan. Varietas I dari pasangan induk betina kuning Bali dengan jantan putih Maluku menunjukkan nilai lebih baik dibandingkan dengan varietas III dan varietas II nilai variasinya lebih tinggi dibandingkan dengan varietas I dan III (Tabel 7).

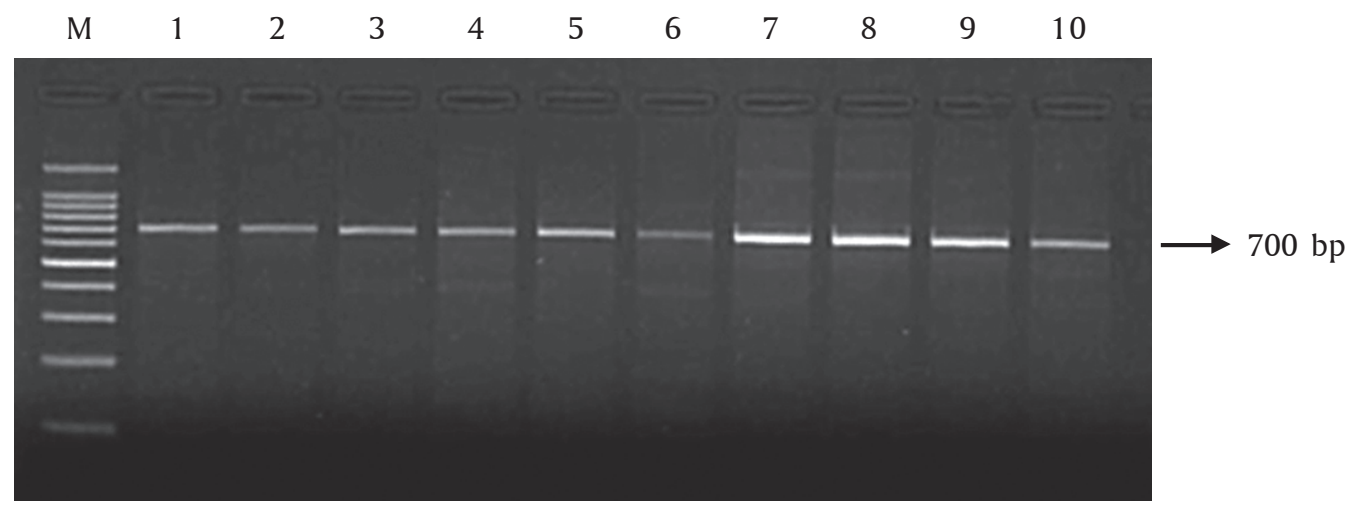

Gambar 4. Hasil amplifikasi genom DNA tiram mutiara F0 dan F1 dengan menggunakan primer Col3 dan CoI. 1-5 (F0), 6-10 (F1)

Figure 4. Result of pearl oyster genom DNA amplification (F0 and F1) using CoI3 and CoI primers. 1-5 (F0), 6-10 (F1) 

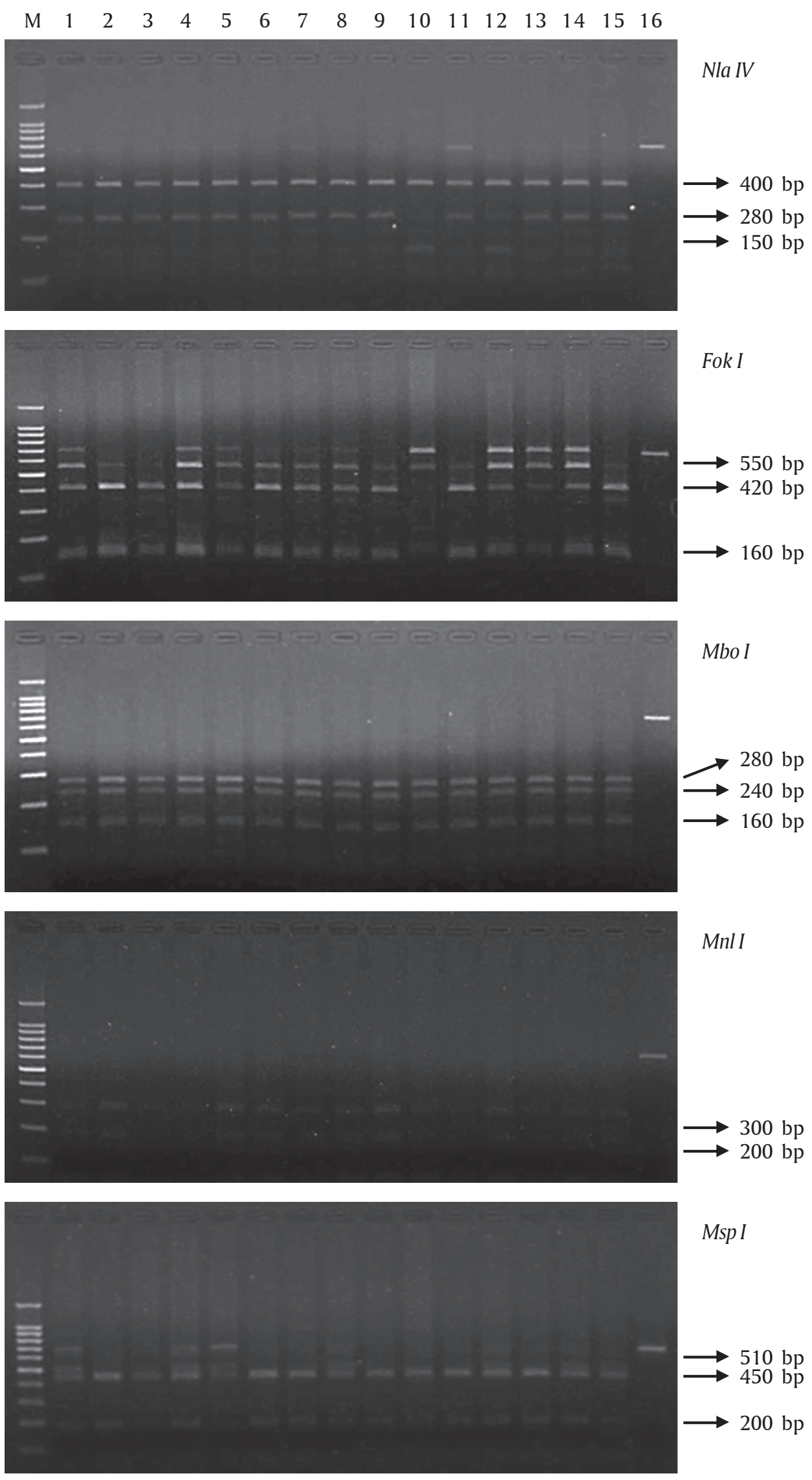

Gambar 5. Pola pemotongan PCR produk DNA tiram mutiara dengan menggunakan lima jenis enzim restriksi (Nla IV, Fok I, Mbo I, Mnl I, dan Msp I)

Figure 5. Cutting pattern of the PCR product of pearl oyster using five restriction enzymes (Nla IV, Fok I, Mbo I, Mnl I, and Msp I) 
Tabel 7. Heterozygositas populasi induk, benih hasil perkawinan silang antar populasi dan dalam populasi yang sama

Table 7. Heterozygosity of broodstocks and the seeds resulted from cross breeding between and within populations

\begin{tabular}{ccc}
\hline Varietas (Variety) & $\begin{array}{c}\text { Populasi } \\
\text { Population }\end{array}$ & $\begin{array}{c}\text { Nilai heterozygositas } \\
\text { Heterozygosity value }\end{array}$ \\
\hline \multirow{6}{*}{ I } & F0 & 0.3755 \\
& F1 & 0.2738 \\
III & F0 & 0.3938 \\
& F1 & 0.2667 \\
IV & F0 & 0.1600 \\
True breed Bali (Supii et al ., 2011) & F1 & 0.0924 \\
& F0 & - \\
True breed Maluku (Supii et al ., 2011) & F1 & - \\
& F1 & 0.2726 \\
& F0 & 0.1304 \\
& F1 & 0.0770 \\
\end{tabular}

Tabel 8. Data skoring perkawinan silang tiram mutiara F0 dan F1 dengan menggunakan lima jenis enzim restriksi (Fok I, Mbo I, Mnl I, Msp I dan Nla IV)

Table 8. Data of pearl oyster cross breeding scoring (F0 and F1) using five restriction enzymes (Fok I, Mbo I, Mnl I, Msp I, and Nla IV)

\begin{tabular}{|c|c|c|c|c|c|c|c|c|c|c|c|c|c|c|c|c|c|c|c|c|}
\hline \multirow{3}{*}{ F0/F1 } & \multicolumn{20}{|c|}{ Enzim restriksi (Restriction enzyme) } \\
\hline & \multicolumn{4}{|c|}{ Fok I } & \multicolumn{4}{|c|}{ Mbo I } & \multicolumn{4}{|c|}{ Mnl I } & \multicolumn{4}{|c|}{ Msp I } & \multicolumn{4}{|c|}{ Nla IV } \\
\hline & I & II & III & IV & I & II & III & IV & I & II & III & IV & I & II & III & IV & I & II & III & IV \\
\hline ㅇ 1 & B & B & B & - & $\mathrm{C}$ & $\mathrm{C}$ & A & & A & A & $\mathrm{B}$ & & B & B & A & & B & A & B & \\
\hline ○ 2 & B & B & B & - & B & B & A & & A & A & A & & A & A & A & & A & A & A & \\
\hline q 3 & B & B & - & - & B & B & - & & A & B & & & A & A & - & & A & A & - & \\
\hline ㅇ 4 & - & B & - & - & D & $\mathrm{C}$ & - & & B & A & & & A & A & - & & A & A & - & \\
\hline ○ 1 & B & B & B & - & D & C & A & & B & A & B & & A & A & A & & B & B & B & \\
\hline đ 2 & B & B & B & - & D & B & A & & A & A & B & & A & A & A & & B & A & B & \\
\hline - 3 & B & B & B & - & D & C & A & & A & A & B & & B & A & A & & B & B & B & \\
\hline o 4 & B & B & - & - & & A & - & & & A & - & & - & B & - & & - & C & - & \\
\hline F1 & \multicolumn{4}{|c|}{ Fok I } & \multicolumn{4}{|c|}{ Mbo I } & \multicolumn{4}{|c|}{ Mnl I } & \multicolumn{4}{|c|}{ Msp I } & \multicolumn{4}{|c|}{ Nla IV } \\
\hline 1 & C & B & C & & C & B & $\mathrm{C}$ & & B & B & B & & B & A & B & & A & A & B & \\
\hline 2 & C & B & C & & C & B & $\mathrm{C}$ & & B & B & B & & A & A & B & & A & A & B & \\
\hline 3 & B & B & B & & B & A & $\mathrm{C}$ & & A & B & B & & A & A & B & & A & A & B & \\
\hline 4 & C & B & B & & C & A & $\mathrm{C}$ & & A & B & B & & B & A & B & & A & A & B & \\
\hline 5 & C & C & C & & B & B & $\mathrm{C}$ & & A & B & B & & B & A & B & & A & A & B & \\
\hline 6 & C & C & C & & C & B & C & & A & B & B & & A & A & B & & A & B & B & \\
\hline 7 & C & C & C & & B & B & $\mathrm{C}$ & & A & B & B & & A & A & B & & A & B & B & \\
\hline 8 & C & C & C & & B & B & C & & A & B & B & & B & A & B & & A & B & B & \\
\hline 9 & C & C & C & & B & B & $\mathrm{C}$ & & A & B & B & & A & A & B & & A & B & B & \\
\hline 10 & B & B & C & & B & B & $\mathrm{C}$ & & A & B & A & & A & A & B & & A & B & C & \\
\hline 11 & C & B & C & & C & A & $\mathrm{C}$ & & A & B & B & & A & A & B & & A & B & B & \\
\hline 12 & C & B & C & & C & B & $\mathrm{C}$ & & A & B & A & & B & A & B & & A & B & C & \\
\hline 13 & C & B & C & & C & A & $\mathrm{C}$ & & B & B & B & & A & A & B & & A & B & B & \\
\hline 14 & C & C & $\mathrm{C}$ & & C & B & $\mathrm{C}$ & & B & B & B & & B & A & B & & A & B & B & \\
\hline 15 & $\mathrm{C}$ & $\mathrm{C}$ & $\mathrm{C}$ & & $\mathrm{C}$ & B & $\mathrm{C}$ & & B & $B$ & B & & B & A & B & & A & B & B & \\
\hline
\end{tabular}


Berdasarkan hal tersebut dapat dikatakan bahwa perkawinan silang antara betina nacre kuning Bali dengan jantan nacre kuning Maluku lebih baik dibandingkan dengan varietas lainnya, akan tetapi observasi di lapangan menunjukkan bahwa benih varietas III yang memberikan sintasan benih (tahap yuwana) terbaik (61\%) dibandingkan dengan varietas lainnya.

Beragamnya nilai variasi genetik pada suatu populasi sangat dipengaruhi oleh letak geografis, perbedaan salinitas dan suhu (Kochn et al.,1984) didukung oleh migrasi, seleksi, genetik drift dan karakteristik kondisi lingkungan serta mekanisme evolusi untuk bertahan hidup dan bereproduksi (Frankham et al., 2002). Sementara Blanc et al. (1996) dalam Susilowati et al. (2009) menyatakan bahwa keragaman intraspesifik, adanya perbedaan interpopulasi tiram sangat dipengaruhi oleh faktor distribusi spasialnya, karena tiram pada masa hidupnya mengalami dua proses tingkat kehidupan yaitu: fase planktonik dan fase bentik, di samping itu juga dipengaruhi oleh migrasi dan seleksi alam yang menyertai pola adaptasinya. Berdasarkan dari data tersebut, dapat dikatakan bahwa induk dan benih tiram mutiara dari hasil perkawinan silang semua varietas merupakan produk biologi yang memiliki nilai tambah dari segi morfologi dan genetik yang sangat mungkin diaplikasikan kepada masyarakat pembudidaya tiram mutiara tanpa mengurangi nilai fitness individu dari masing-masing populasi.

\section{KESIMPULAN}

1. Perkawinan silang tiram mutiara dari dua populasi (Bali dan Maluku) dengan warna nacre kuning dan putih menghasilkan tiga varietas yaitu: varietas I ( $\mathrm{K} \times \mathrm{P})$, varietas II ( $\mathrm{K} \times \mathrm{K})$ dan varietas III ( $\mathrm{P} \times$ K)

2. Sintasan (SR) pada fase pediveliger dari ketiga varietas yaitu masing-masing $65 \%$, 59\% dan $45 \%$. Sementara ditinjau dari segi pertumbuhan, benih hasil perkawinan silang dari varietas III menunjukkan pertumbuhan yang lebih baik dengan kisaran panjang cangkang pada umur dua bulan pemeliharaan di laut sebesar $3,0-4,5 \mathrm{~cm}$

\section{DAFTAR ACUAN}

Ath-thar, M.H.F., Prakoso, V.A., Nugroho, E., \& Gustiano, R. (2011). Heterosis, maternal dan individual effect pada hibrida antara ikan mas Rajadanu, Majalaya, Subang, dan Kuningan.

Bermingham, E. (1990). Mithochondrial DNA and the analysis of fish population structure. In: D.H. Withmore (Ed.), Electrophoretic and isoelectric fucosing techniques in Fisheries management. CRC Press. Inc. Buca Raton. Florida, p. 107-129.
Bartley, D.M., Rana, K., \& Immink, A.J. (2001). The use of inter-specific hybrids in aquaculture and fisheries. Reviews in Fish Biology and Fisheries, $10,325-337$.

Dhoe, S.B., Supriya, \& Juliaty, E. (2001). Biologi tiram mutiara. Pembenihan tiram mutiara (Pinctada maxima). Balai Budidaya Laut Lampung. Juknis seri no. 6, hlm. 6-12.

Direktorat Jenderal Perikanan Budidaya. (2004). Master plan program pengembangan kawasan budidaya laut. Departemen Kelautan dan Perikanan. Jakarta.

Doroudi. M.S., \& Southgale, P.C. (2002). The influence of algal ration and larva density on growth and survival of black lip pearl oyster Pinctada margaritifera (L) larvae. Aquaculture research vol 31. Issue 8-9, 621-626.

Ellis \& Haws, M. (2002). The Basic Method of Pearl Farming: A Layman's Manual. CTS Publication No. 127.

Falcouner, D.S., \& Mackay, T.F.C. (1996). Introduction to quantitative genetics. Longman, Harow, UK, $464 \mathrm{pp}$.

Frankham, R., Ballou, J.D., \& Briscoe, D.A. (2002). Introduction to conservation genetics. Cambrige University press, $473 \mathrm{pp}$.

Gaffney, P.M., Stardish, K., \& Allen, Jr. (1993). Hybridization among Crassostrea species a review. Aquaculture, 116, 1-13.

Hanafi, A., Andriyanto, W., Riandi, J., \& Septory, R. (2007). Pengembangan sistem pengelolaan sumberdaya pesisir untuk budidaya laut yang berkelanjutan. Laporan hasil riset. Balai Besar Riset Perikanan Budidaya Laut Gondol. Departemen Kelautan dan Perikanan, hlm. 163-189.

Hanafi, A., Andriyanto, W., Suko, I., Slamet, B., Riandi, J., Septory, R., \& Sutarmat, T. (2008a). Manajemen lingkungan perikanan budidaya laut sebagai usaha pemanfaatan sumberdaya ramah lingkungan. Laporan hasil riset. Balai Besar Riset Perikanan Budidaya Laut Gondol. Departemen Kelautan dan Perikanan, hlm. 131-150.

Hanafi, A., Supii, A.I., Susanto B., \& Andriyanto, W. (2008b). Penelitian pengembangan budidaya tiram mutiara (Pinctada maxima) dengan perbaikan manajemen pemeliharaan dan identifikasi karakteristik aspek lingkungan budidaya induk tiram mutiara. Laporan hasil riset. Balai Besar Riset Perikanan Budidaya Laut Gondol. Departemen Kelautan dan Perikanan, hlm. 201-215.

Hamzah, M.S. (2007). Variasi Musiman Beberapa Parameter Oseanografi, Kaitannya dengan Kisaran Batas Ambang Toleransi Kehidupan Tiram Mutiara (Pinctada maxima) Dari Beberapa Lokasi Di 
Kawasan Tengah Indonesia. PROSIDING SEMINAR NASIONAL. Pusat Riset Perikanan Budidaya Badan Riset Kelautan dan Perikanan Departemen Kelautan dan Perikanan bekerja sama dengan Jurusan Ilmu Kelautan Fakultas Perikanan dan Ilmu Kelautan Universitas Diponegoro. Semarang.

Hermawan, A. (2007). Pemeliharaan kerang hijau (Perna viridis L.) dengan pakan campuran beberapa jenis phytoplankton. Prosiding Seminar Moluska dan Penelitian Konservasi dan Ekonomi, hlm. 29-35.

Kochn, R.K., Hall, J.G., Innes, D.J., \& Zora A.J. (1984). Genetic differenciation of Mytilus edulis in Eastern North America. Marine Biology, 79, 117-126.

Lind, C.E., Evans, B.S., Knauer, J., Taylor, J.J.U., \& Jerry, D.R. (2009). Decreased genetic diversity and a reduced effective population size in cultured silver-lipped pearl oysters (Pinctada maxima). Aquaculture, 286,12-19.

Ovenden, J. (2000). Development of Restriction Enzymes Markers for Red Snapper (Lutjanus erythropterus and Lutjanus malabaricus) Stock Descrimination Using Genetics Variation in Mithocondrial DNA. Molecular Fisheries Laboratory. Southern Fisheries Centre. Produced For CSIRO Marine Laboratories as Part of The ACIAR Indonesia Snapper Project.

Rose, R.A., Dybdahl, R.E., \& Harders, S. (1990). Reproductive cycle of the western Australian Silver Lip pearl oyster Pinctada maxima (Jameson) (Mollusca; Pteriidae). J. Shellfish, Res., 9, 261-272.

Susilowati, R., Sumantadinata, K., Soelistyowati, D., \& Sudradjat, A. (2009). Karakteristik genetik po- pulasi tiram mutiara (Pinctada margaritifera) terkait dengan distribusi geografisnya di perairan Indonesia. Jurnal Riset Akuakultur, 4(1), 47-52.

Supii, A.I., Sudewi., \& Rusdi, I. (2009). Penelitian pembenihan Tiram Mutiara (Pinctada maxima) dengan managemen pergantian air dan perbedaan ukuran tebar awal benih Tiram Mutiara di laut. Laporan teknis. BBRPBL Gondol Bali.

Supii, A.I., Wardana, I.K., Sudewi., Priono, A., \& Haryanti. (2011). Pematangan gonad induk dan seleksi benih tiram mutiara (Pinctada maxima) dengan warna cangkang dalam putih. Laporan hasil penelitian. Balai Besar Penelitian dan Pengembangan Budidaya Laut Gondol Bali, hlm. 79-90.

Wang, A.M., Li, D.F., Gu, Z.F., Wang, A., Shi, Y.H., Ye, H., \& Qu, Y.B. (2005). Evaluation of growth and economic traits of Chinese-Indian F1 hybrid of the pearl oyster Pinctada martensii. Abstracts of the annual international meeting of world aquaculture society in Bali, 415 pp.

Williams, S.T., \& Banzie, J.A.H. (1997). Indo-West Pacific pattern of genetic Differenciation in HighDispersal Starfish Linckia laevigata. Mol. Ecol., 6, 559-573.

Winanto, T. (2004). Memproduksi benih tiram mutiara. Penebar Swadaya. Jakarta.

Yu, D.H., Huang, G., Guo Y., Wang, X., \& Wang, A. (2009). Genetic characteristics of hybrid populations derived by crossing Chinese and Indian pearl oysters, Pinctada fucata, based on AFLP markers. African Journal of Agricultural Research, 4(7), 659664. 